\title{
Novel VLDLR microdeletion identified in two Turkish siblings with pachygyria and pontocerebellar atrophy
}

\author{
Luis E. Kolb • Zulfikar Arlier • Cengiz Yalcinkaya • Ali K. Ozturk • \\ Jennifer A. Moliterno • Ozdem Erturk • Fatih Bayrakli • Baris Korkmaz • \\ Michael L. DiLuna • Katsuhito Yasuno • Kaya Bilguvar • Tayfun Ozcelik • \\ Beyhan Tuysuz $\cdot$ Matthew W. State $\cdot$ Murat Gunel
}

Received: 23 June 2009 / Accepted: 15 December 2009/Published online: 15 January 2010

(C) Springer-Verlag 2010

\begin{abstract}
Congenital ataxia with cerebellar hypoplasia is a heterogeneous group of disorders that presents with motor disability, hypotonia, incoordination, and impaired motor development. Among these, disequilibrium syndrome describes a constellation of findings including nonprogressive cerebellar ataxia, mental retardation, and cerebellar hypoplasia following an autosomal recessive pattern of inheritance and can be caused by mutations in the Very Low Density Lipoprotein Receptor (VLDLR). Interestingly, while the majority of patients with VLDLassociated cerebellar hypoplasia in the literature use bipedal gait, the previously reported patients of Turkish decent have demonstrated similar neurological sequelae, but rely on quadrupedal gait. We present a consanguinous Turkish family with two siblings with cerebellar atrophy, predominantly frontal pachygyria and ataxic bipedal gait, who were found to have a novel homozygous deletion in the VLDLR gene identified by using high-density single nucleotide
\end{abstract}

Luis E. Kolb and Zulfikar Arlier contributed equally to this work.

L. E. Kolb · Z. Arlier · A. K. Ozturk · J. A. Moliterno •

F. Bayrakli • M. L. DiLuna $\cdot$ K. Yasuno $\cdot$ K. Bilguvar $\cdot$ M. Gunel

Department of Neurosurgery, Neurobiology, Program on

Neurogenetics Yale University School of Medicine,

New Haven, CT, USA

L. E. Kolb - Z. Arlier • A. K. Ozturk - J. A. Moliterno •

F. Bayrakli $\cdot$ M. L. DiLuna $\cdot$ K. Yasuno $\cdot K$. Bilguvar

M. W. State $\cdot$ M. Gunel $(\varangle)$

Department of Genetics, Program on Neurogenetics Yale

University School of Medicine,

New Haven, CT, USA

e-mail: murat.gunel@yale.edu

C. Yalcinkaya $\cdot$ O. Erturk $\cdot$ B. Korkmaz

Division of Child Neurology, Department of Neurology, Istanbul University Cerrahpasa Faculty of Medicine,

Istanbul, Turkey polymorphism microarrays for homozygosity mapping and identification of CNVs within these regions. Discovery of disease causing homozygous deletions in the present Turkish family capable of maintaining bipedal movement exemplifies the phenotypic heterogeneity of VLDLRassociated cerebellar hypoplasia and ataxia.

Keywords VLDLR · Cerebellar hypoplasia · Pachygyria . Disequilibrium syndrome

\section{Introduction}

Non-progressive human congenital ataxias are a rare, heterogeneous group of disorders characterized by motor disability, muscular hypotonia, incoordination, and impaired motor development [1-3]. Patients with these disorders initially present with generalized symptoms, such

\section{T. Ozcelik}

Department of Molecular Biology and Genetics,

Faculty of Science and Institute of Materials Science and Nanotechnology, Bilkent University,

Ankara, Turkey

\section{B. Tuysuz}

Division of Genetics, Department of Pediatrics, Istanbul University Cerrahpasa Faculty of Medicine, Istanbul, Turkey

M. W. State

Child Study Center and Department of Psychiatry,

Yale University School of Medicine,

New Haven, CT, USA 
as the delayed achievement of motor milestones and hypotonia during the early postnatal period, followed by the gradual onset of ataxic gait during the first few years of life. This heterogeneous group of disorders is also associated with other pathologic findings, including brain malformations, genetic syndromes, and congenital infections. Of the associated brain malformations, cerebellar hypoplasia is the most common, occurring in approximately $50 \%$ of cases [3]. In the most severe cases, patients can have marked hypoplasia of the vermis with mild to moderate involvement of the neocerebellum [3]. While some patients improve as motor functions develop, others significantly worsen early during infancy as motor demands increase on coordination [3].

Evaluation of inherited congenital ataxia syndromes with cerebellar hypoplasia has led to the identification of novel genes involved in the embryonic development of the cerebellum. Mutations in the Reelin gene have been found to cause autosomal recessive lissencephaly with cerebellar hypoplasia [4], while PTFla mutations have been linked to cerebellar agenesis and neonatal diabetes [5]. Studies on Joubert Syndrome, a group of recessively inherited conditions characterized by congenital ataxia, hypotonia, episodic breathing, mental retardation, and specific malformations of the brainstem, cerebellum, and peduncles, have led to the discovery of several mutations. The involved genes, including AHI1, NPHP1, CEP290, MKS3, and $R P G R 1 L$, are responsible for encoding cilia-like functioning and modular scaffolding proteins [6-17].

More recently, mutations in the Very Low Density Lipoprotein Receptor (VLDLR) have been identified in patients of Turkish [18, 19], Iranian [20], and Hutterite [21] descent with non-progressive cerebellar ataxia, mental retardation, and cerebellar hypoplasia following an autosomal recessive pattern of inheritance [22, 23]. Such neurological sequelae can be explained by the intricate role of the VLDLR protein in the Reelin signaling pathway, which is important in cerebellogenesis [21]. The term "disequilibrium syndrome" (DES), originally coined by Hagberg in association with cerebral palsy, was later used to describe a similar constellation of findings associated with the deletion of the $V L D L R$ gene and the adjacent noncoding sequence in the Hutterite population (referred to as DES-H for Hutterite population) [23, 24]. Patients with DES have also been found to suffer from delayed ambulation, strabismus, and short stature (15\%) and have mild cortical simplification on magnetic resonance imaging (MRI). Since then, others have proposed referring to this syndrome as "VLDLR-associated cerebellar hypoplasia" in an effort to emphasize the molecular pathogenesis [21]. Irrespective of semantics, these observations, coupled with advances in understanding the roles of these genes in mouse models, have further enhanced our knowledge of the
Reelin-VLDLR pathway and its role in the developing cerebellum.

Copy number variation (CNV) analysis in conjunction with traditional mutation discovery methods such as homozygosity mapping and linkage analysis has emerged as a powerful new tool for the identification of novel disease causing mutations [25]. We present two siblings, born in a consanguineous marriage, both of whom have cerebellar atrophy and diffuse pachygyria, as well as mental retardation and markedly ataxic bipedal gait. By using high-density single nucleotide polymorphism (SNP) gene chips to identify CNVs within areas of homozygosity, these siblings were found to have a novel homozygous deletion in the VLDLR gene.

\section{Materials/methods}

Study subjects/whole genome genotyping After obtaining written consent at Cerrahpasa Faculty of Medicine, Istanbul, Turkey, blood samples were collected from all available family members, and DNA samples were isolated using standard protocols. Genotyping was performed using the Human610-Quad Beadchip (containing 620,089 SNPs; Illumina, San Diego, CA, USA) at Yale. All procedures were performed according to the manufacturer's protocol. Briefly, $200 \mathrm{ng}$ of genomic DNA was amplified, fragmented, and hybridized to the array, and products were fluorescently labeled and scanned with Illumina Beadstation scanner. Raw data was then uploaded to Beadstudio v3.3 genotyping software (Illumina, San Diego, CA, USA) for further analysis. Homozygosity mapping was performed with this software and subsequently further evaluated by visual inspection. Copy number analysis was done using PennCNV [26], a CNV detection program based on a Hidden Markov model. Identified CNVs were confirmed by visual inspection of plotted intensity data on the Beadstudio v3.3 program. The overlap between areas of homozygosity with the identified CNVs was confirmed visually.

PCR/quantitative PCR Primers for each VLDLR exon were designed using Primer3 [27]. BLAST analysis [28] showed the sequences to be specific for the region of interest. Quantitative PCR (qPCR) reactions were carried out in standard fashion. Briefly, each reaction included the optimal primer concentration, $10 \mathrm{ng}$ DNA, $7.5 \mu \mathrm{l}$ of 2XSYBR Green master mix (Applied Biosystems, Foster City, CA, USA) in a volume of $15 \mu$ l. Cycling conditions began with $5 \mathrm{~min}$ at $50^{\circ} \mathrm{C}$ followed by $10 \mathrm{~min}$ at $95^{\circ} \mathrm{C}$. This was followed by 40 cycles of: $15 \mathrm{~s}$ at $95^{\circ} \mathrm{C}, 1 \mathrm{~min}$ at $60^{\circ} \mathrm{C}$. qPCR was carried out on an ABI Prism 7900HT instrument with a 384-well block (Applied Biosystems, Foster City, CA, USA). All reactions were performed in triplicate. A 
sample was considered to have a failed reaction and needed repeating in the event that more than one of the triplicates failed.

\section{Results}

Phenotypic information

The affected siblings are a product of a self-reported consanguineous first cousin marriage, ages 11 (NG 374-1) and 8 (NG 374-2) at the time of presentation (Fig. 1a). They are the only children of the family and were born, via uneventful cesarean sections with normal weights and heights at birth. They were raised in an urban setting. Their motor development was markedly delayed with head holding beginning at 40 days, and sitting without support at age one. Intensive physical therapy was initiated at this time. By 18 months, they were walking with minimal support from their hands.

On neurological examination, the patients display severely ataxic bipedal gait. They do not exhibit tremor, but do have significant dysarthria, dysmetria, and dysdiadochokinesis, as well as diffusely hyperactive deep tendon reflexes. The children are unable to construct full sentences. The older patient exhibits selective mutism, constructing partial sentences only when he is talking to himself.

Magnetic resonance imaging scans of the brains of the children are markedly similar to each other, demonstrating predominantly frontal pachygyria and cerebellar atrophy (Fig. 1b).

\section{Genotype analysis}

Homozygosity mapping of the affected siblings on Beadstudio v3.3 identified a $10 \mathrm{Mb}$ homozygous block shared by both patients on chromosome 9 starting at 102,542 bps and ending at $10,533,899 \mathrm{bps}$. Within this homozygous interval, copy number variation analysis of both siblings on Human610-Quad beadchips using the PennCNV algorithm showed a shared homozygous deletion on chromosome 9 with the first and last deleted SNP markers being rs2375994 (position, 2,621,092 bp) and rs10967306 (position, 2,630,805 bp; Fig. 2a). This finding was confirmed by visual inspection of the plotted intensities on Beadstudio v3.3. Compared with previously published reports of genomic variation in the Database of Human Variation
A.

I.

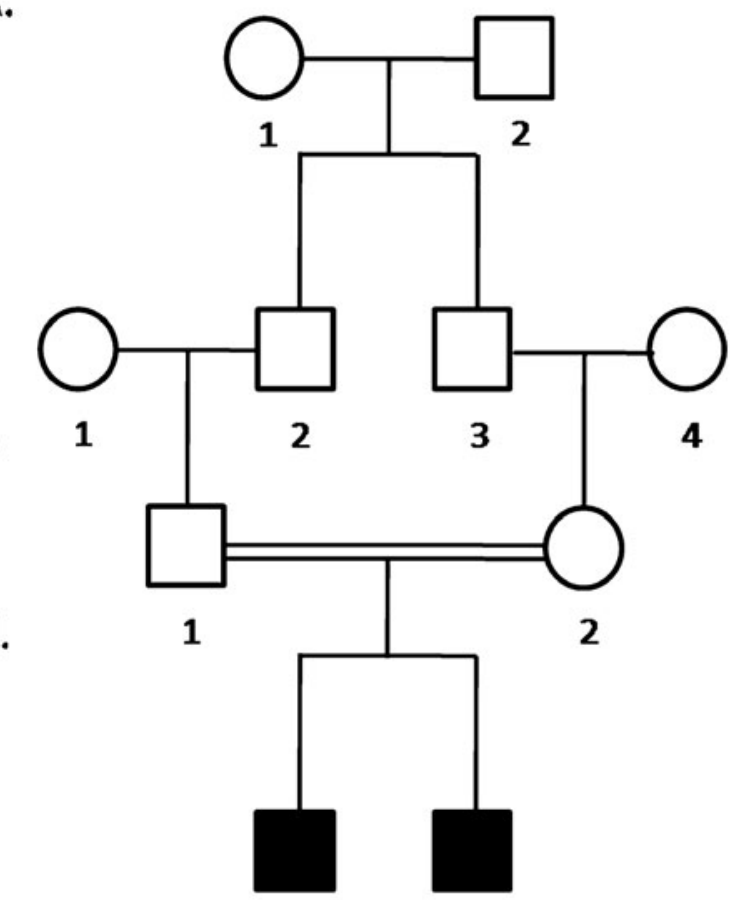

II.

IV.

1
B.
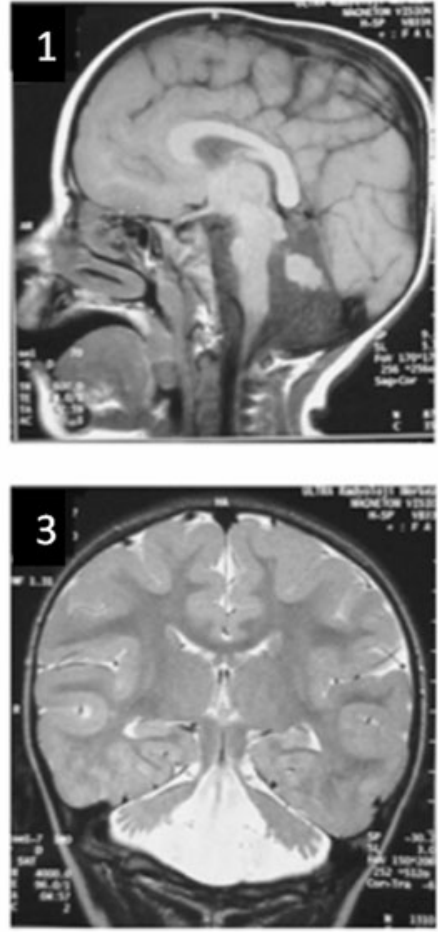

NG 374-1
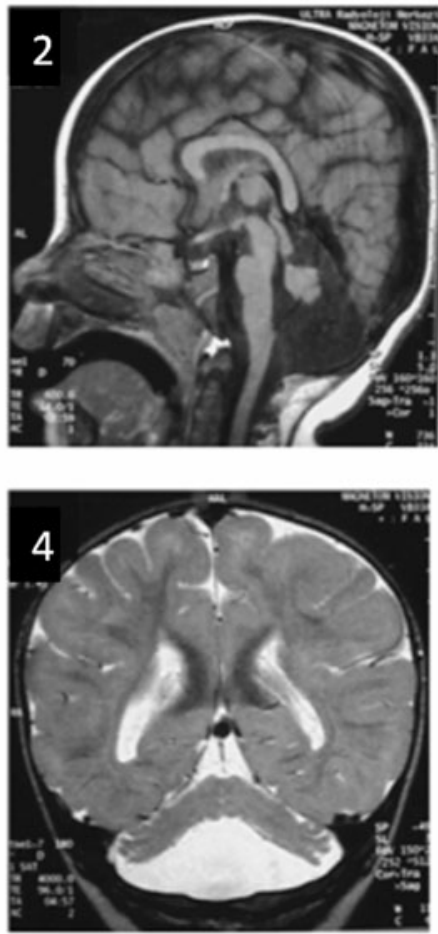

NG 374-2

Fig. 1 a Pedigree of family NG-374. Affected members are identified by filled symbols. Circles represent female and squares represent male family members. b Magnetic resonance imaging of the brain of affected siblings. Sagittal T1 $(1,2)$ and coronal T2 $(3,4)$ weighted

images demonstrate diffuse pachygyria of the cerebrum and hypoplasia of the cerebellar vermis in both patients, NG 374-1 $(1,3)$ and NG $374-2(2,4)$ 

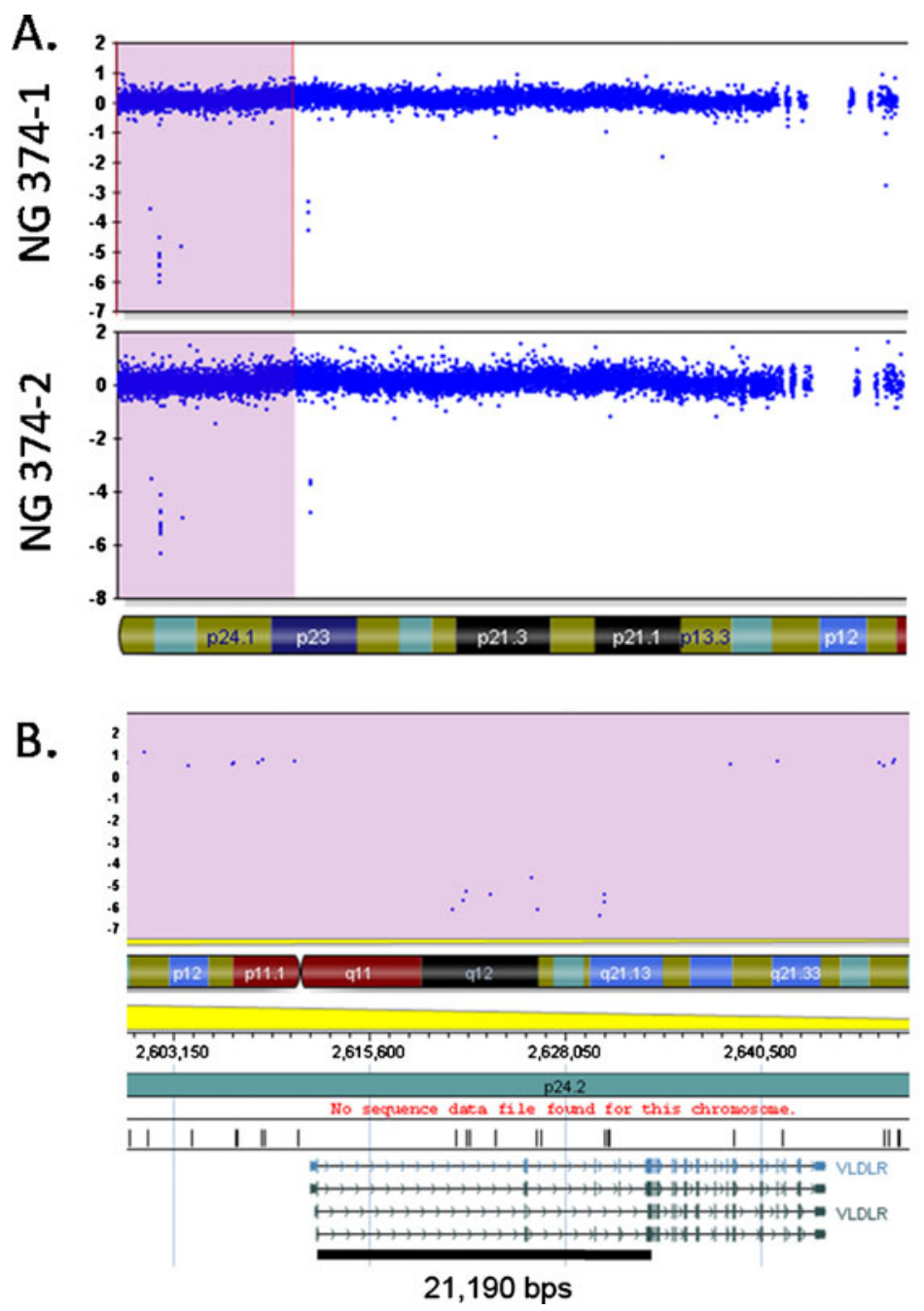

C.

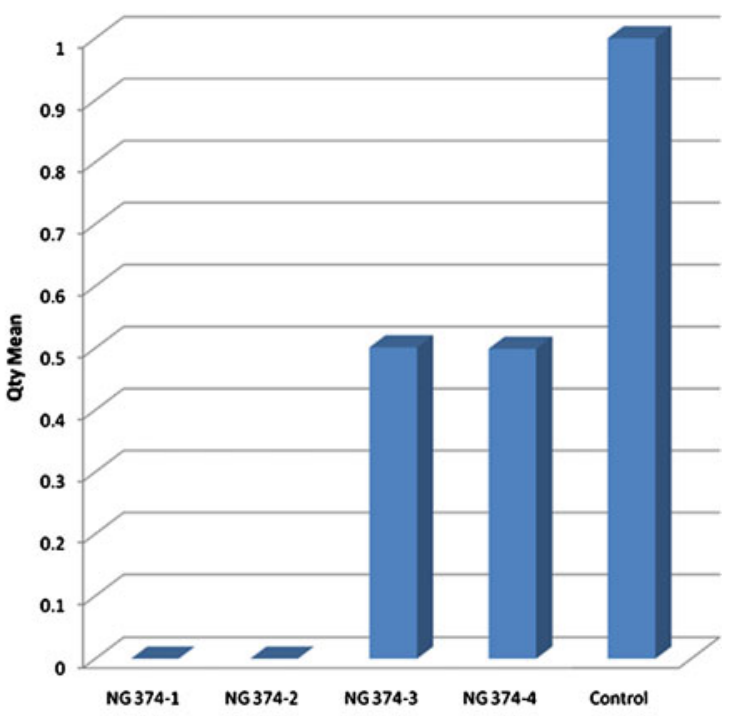

Fig. 2 a Genotyping signal intensity plot demonstrates a microdeleted segment on chromosome 9 that affects the VLDLR gene. Scatter points represent normalized $\log \mathrm{R}$ ratios for probe intensities along the chromosome with negative values that are less than -1 representing homozygous deletions. Shaded areas represent areas of autozygosity.

(http://projects.tcag.ca/variation/), this area does not appear to be an area of common variability. In addition, homozygous deletions in the VLDLR gene were absent in 300 other Turkish patients with malformations of cortical development who were genotyped as controls.

PCR analysis of the patients confirmed a homozygous deletion in the VLDLR gene encompassing exons 2, 3, and 4 and no comparable homozygous deletion in the parents. Mapping and crossing of the breakpoint was performed to the base pair level. Using PCR primers flanking the breakpoint, the region was amplified in both patients. Sequence analysis of PCR product of this experiment revealed a 21,190 bp deletion beginning in the 5' untranslated region of the transcript and extending through exons 2, 3, 4, and parts of exons 1 and 5. The deletion corresponds to bps 2,612,148-2,633,338 on chromosome 9 b Magnified view of the $21,190 \mathrm{bps}$ deleted region which is marked by the black bar. c Quantitative PCR results of exon 3 of the VLDLR gene within the deleted segment confirms homozygous and heterozygous deletions in patients (NG 374-1 and NG 374-2) and parents (NG 374-3 and NG 374-4), respectively

(Fig. 2b). qPCR analysis of the region confirmed the homozygous deletion in both siblings and also revealed heterozygous deletions in both parents when compared to controls (Fig. 2c).

\section{Discussion}

The VLDLR gene is composed of 19 exons, spans a $32 \mathrm{~kb}$ genomic interval, and encodes a protein that belongs to the low-density lipoprotein (LDL) gene family. Two isoforms of the receptor have been identified in humans: type I is a complete version expressed in the heart and skeletal muscles and Type II, which lacks an O-linked sugar domain and can be found in various non-muscular tissues, including the kidney, spleen, and brain [29]. Though the 
importance of the VLDLR protein may be most commonly known for its role in fatty acid metabolism, it also serves as an integral part of the Reelin Signaling pathway. Specifically, within the developing cerebellum, granule cells secrete the glycoprotein reelin, which subsequently binds to VLDLR, triggering an intracellular signaling cascade that allows neuroblasts to complete migration [30,31]. Through this interaction, reelin regulates the alignment of Purkinje cells, which ultimately guides the formation of the internal granular cell layer in the cerebellum [32].

Mutations in the VLDRL gene have been well described in both animal models and in humans and underscore its importance in cerebellogenesis. While mutations in Reln in the mouse result in ataxic gait and trembling [21, 33], $\mathrm{Vldlr}^{-1-}$ mice appear to be grossly and neurologically normal. Upon further evaluation, these animals have hypoplastic cerebella with reduced foliation, heterotopic Purkinje cells and radially aligned cortical neurons that have failed to properly disperse $[21,34,35]$. In humans, $V L D L R$ mutations have been found to cause the DES phenotype. The first $V L D L R$ mutation was observed in the Hutterite population [21] whereby patients exhibited nonprogressive cerebellar ataxia, mental retardation, and cerebellar hypoplasia following an autosomal recessive pattern of inheritance $[22,23]$. These patients were found to have a 199-kb homozygous deletion encompassing the complete $V L D L R$ as well as adjacent extragenic, and potentially regulatory, regions and possibly a second gene. Thus, it was unclear whether an isolated mutation in VLDRL could explain the syndrome in its entirety. Follow-up studies in an Iranian family with DES subsequently revealed a homozygous nucleotide substitution in exon 10 resulting in a premature stop codon in the VLDLR gene [20].

Since then, additional mutations have been found, including the first case of a compound heterozygous mutation described in a 26-month-old non-consanguineous patient born to Irish-German and Scottish-German parents [36]. This child suffered from hypotonia and motor delay that led to the identification of characteristic MRI findings of hypoplasia of the inferior portion of the vermis and cerebellar hemispheres, along with simplified sulcal pattern. The compound heterozygous mutation, composed of a missense mutation in exon 11 and a frameshift mutation in exon 12. Thus, it has been concluded that a truncated VLDRL protein can serve as the sole genetic predecessor in DES [20, 21, 34], with our findings providing additional support.

Although patients with VLDLR-associated cerebellar hypoplasia may suffer from the delayed onset of severely ataxic ambulation, the majority of the literature reports patients who are able to use bipedal gait $[18,19,21,36]$. Four Turkish kindreds, however, have been described with a remarkably similar rare autosomal recessive neurodevelopmental condition characterized by cerebellar and cortical hypoplasia accompanied by mental retardation and primitive and dysarthric speech. Interestingly, members of these families most notably exhibit quadrupedal locomotion and it was therefore postulated that such a difference in gait might render this syndrome genetically distinct also referred to as Uner Tan syndrome [37]). One non-sense and one frameshift mutation (in two separate families) resulting in premature stop codons in exons 5 and 17 of $V L D L R$, presumably causing the $V L D L R$ protein to lack transmembrane and signaling domains, were identified in these Turkish families with features similar to DES, but with quadrupedal gait.

In addition to the VLDLR locus on chromosome 9, genetic heterogeneity of quadrupedal gait has been shown [18]. One Turkish family maps to chromosome 17 [38] and an Iraqi family links to chromosome 8 with a recent study identifying $C A 8$ as the causative gene [39]. Finally, other families exclude linkage to any of these three loci ([18] and personal communication with Dr. Tayfun Ozcelik).

It has remained controversial as to why certain patients with congenital ataxia and cerebellar hypoplasia display quadrupedal locomotion, while others are able to achieve and maintain bipedal gait. While some have raised the possibility that the type of locomotion (i.e., bipedal versus quadrupedal) may simply be different symptoms of the same disease, others postulate that quadrupedal locomotion is not a manifestation of the genetic disease, but rather an adaptation to the environment, such that patients with $V L D L R$ deletions use their hands when ambulating as a means to compensate for their severe truncal ataxia [41, 42]. Rural topography, imitation of the behavior demonstrated by other affected siblings, lack of medical attention, and social acceptance of quadrupedal gait may foster its development in certain patients.

Including the present report and the original description in the Hutterites, seven different mutations in ten families have been described in the VLDLR gene to date. Structural examination of the gene and the defective protein has not revealed any identifiable portion that appears to be responsible for quadrupedal gait [21, 40]. A stop codon in exon 5 and a frameshift mutation in exon 17 both lead to quadrupedal gait in Turkish families with congenital ataxia and cerebellar hypoplasia [37], whereas a stop codon in exon 10 [20], the recent compound heterozygous mutation affecting exons 11 and 12 [36], and our report of a deletion affecting exons 1-5 resulted in patients with similar neurological findings and bipedal, ataxic gait. Based on these findings, we posit quadrupedal and bipedal gait are different manifestations of the same genetic syndrome and represent a spectrum of symptomatic disease resulting from various VLDLR mutations. The clinical manifestations of 
$V L D L R$ mutation, specifically with regards to ambulation, are likely the product of a complex interaction between genetic makeup and the environment, and cannot be predicted based on mutation alone.

\section{Conclusion}

Mutations in the $V L D L R$ gene cause an autosomal recessive inherited syndrome characterized by cerebellar hypoplasia, ataxia, and mental retardation. The type of mutation does not appear to predict the clinical manifestation of the disease, specifically with regards to gait.

Acknowledgments Funding for this study came from the Program on Neurogenetics at the Yale University School of Medicine (MG, MWS). We are greatly indebted to the patients for their participation in this study.

Financial disclosure The authors report no competing financial interests.

Conflict of interest statement The authors report no conflict of interest.

\section{Glossary of terms}

SNP Single nucleotide polymorphism

CNV Copy number variation

\section{References}

1. Esscher E, Flodmark O, Hagberg G, Hagberg B (1996) Nonprogressive ataxia: origins, brain pathology and impairments in 78 swedish children. Dev Med Child Neurol 38:285-296

2. Sanner G, Hagberg B (1974) 188 cases of non-progressive ataxic syndromes in childhood. Aspects of aetiology and classification. Neuropadiatrie 5:224-235

3. Steinlin M (1998) Non-progressive congenital ataxias. Brain Dev 20:199-208

4. Hong SE, Shugart YY, Huang DT, Shahwan SA, Grant PE, Hourihane JO, Martin ND, Walsh CA (2000) Autosomal recessive lissencephaly with cerebellar hypoplasia is associated with human RELN mutations. Nat Genet 26:93-96

5. Sellick GS, Barker KT, Stolte-Dijkstra I, Fleischmann C, Coleman RJ, Garrett C, Gloyn AL, Edghill EL, Hattersley AT, Wellauer PK, Goodwin G, Houlston RS (2004) Mutations in PTF1A cause pancreatic and cerebellar agenesis. Nat Genet 36:1301-1305

6. Arts HH, Doherty D, van Beersum SE, Parisi MA, Letteboer SJ, Gorden NT, Peters TA, Märker T, Voesenek K, Kartono A, Ozyurek H, Farin FM, Kroes HY, Wolfrum U, Brunner HG, Cremers FP, Glass IA, Knoers NV, Roepman R (2007) Mutations in the gene encoding the basal body protein RPGRIP1L, a nephrocystin-4 interactor, cause Joubert syndrome. Nat Genet 39:882-888

7. Baala L, Romano S, Khaddour R, Saunier S, Smith UM, Audollent S, Ozilou C, Faivre L, Laurent N, Foliguet B, Munnich A, Lyonnet S, Salomon R, Encha-Razavi F, Gubler MC, Boddaert N, de Lonlay P, Johnson CA, Vekemans M, Antignac C, Attie-
Bitach T (2007) The Meckel-Gruber syndrome gene, MKS3, is mutated in Joubert syndrome. Am J Hum Genet 80:186-194

8. Brancati F, Iannicelli M, Travaglini L, Mazzotta A, Bertini E, Boltshauser E, D'Arrigo S, Emma F, Fazzi E, Gallizzi R, Gentile M, Loncarevic D, Mejaski-Bosnjak V, Pantaleoni C, Rigoli L, Salpietro CD, Signorini S, Stringini GR, Verloes A, Zabloka D, Dallapiccola B, Gleeson JG, Valente EM, International JSRD Study Group (2009) MKS3/TMEM67 mutations are a major cause of COACH Syndrome, a Joubert Syndrome related disorder with liver involvement. Hum Mutat 30:E432-E442

9. Brancati F, Travaglini L, Zablocka D, Boltshauser E, Accorsi P, Montagna G, Silhavy JL, Barrano G, Bertini E, Emma F, Rigoli L, International JSRD Study Group, Dallapiccola B, Gleeson JG, Valente EM (2008) RPGRIP1L mutations are mainly associated with the cerebello-renal phenotype of Joubert syndrome-related disorders. Clin Genet 74:164-170

10. Castori M, Valente EM, Donati MA, Salvi S, Fazzi E, Procopio E, Galluccio T, Emma F, Dallapiccola B, Bertini E, Italian MTS Study Group (2005) NPHP1 gene deletion is a rare cause of Joubert syndrome related disorders. J Med Genet 42:e9

11. Delous M, Baala L, Salomon R, Laclef C, Vierkotten J, Tory K, Golzio C, Lacoste T, Besse L, Ozilou C, Moutkine I, Hellman NE, Anselme I, Silbermann F, Vesque C, Gerhardt C, Rattenberry E, Wolf MT, Gubler MC, Martinovic J, Encha-Razavi F, Boddaert N, Gonzales M, Macher MA, Nivet H, Champion G, Berthélémé JP, Niaudet P, McDonald F, Hildebrandt F, Johnson CA, Vekemans M, Antignac C, Rüther U, Schneider-Maunoury S, Attié-Bitach T, Saunier S (2007) The ciliary gene RPGRIP1L is mutated in cerebello-oculo-renal syndrome (Joubert syndrome type B) and Meckel syndrome. Nat Genet 39:875-881

12. Dixon-Salazar T, Silhavy JL, Marsh SE, Louie CM, Scott LC, Gururaj A, Al-Gazali L, Al-Tawari AA, Kayserili H, Sztriha L, Gleeson JG (2004) Mutations in the AHI1 gene, encoding jouberin, cause Joubert syndrome with cortical polymicrogyria. Am J Hum Genet 75:979-987

13. Ferland RJ, Eyaid W, Collura RV, Tully LD, Hill RS, Al-Nouri D, Al-Rumayyan A, Topcu M, Gascon G, Bodell A, Shugart YY, Ruvolo M, Walsh CA (2004) Abnormal cerebellar development and axonal decussation due to mutations in AHI1 in Joubert syndrome. Nat Genet 36:1008-1013

14. Joubert M, Eisenring JJ, Robb JP, Andermann F (1969) Familial agenesis of the cerebellar vermis. A syndrome of episodic hyperpnea, abnormal eye movements, ataxia, and retardation. Neurology 19:813-825

15. Parisi MA, Bennett CL, Eckert ML, Dobyns WB, Gleeson JG, Shaw DW, McDonald R, Eddy A, Chance PF, Glass IA (2004) The NPHP1 gene deletion associated with juvenile nephronophthisis is present in a subset of individuals with Joubert syndrome. Am J Hum Genet 75:82-91

16. Valente EM, Silhavy JL, Brancati F, Barrano G, Krishnaswami SR, Castori M, Lancaster MA, Boltshauser E, Boccone L, AlGazali L, Fazzi E, Signorini S, Louie CM, Bellacchio E, International Joubert Syndrome Related Disorders Study Group, Bertini E, Dallapiccola B, Gleeson JG (2006) Mutations in CEP290, which encodes a centrosomal protein, cause pleiotropic forms of Joubert syndrome. Nat Genet 38:623-625

17. Wolf MT, Saunier S, O'Toole JF, Wanner N, Groshong T, Attanasio M, Salomon R, Stallmach T, Sayer JA, Waldherr R, Griebel M, Oh J, Neuhaus TJ, Josefiak U, Antignac C, Otto EA, Hildebrandt F (2007) Mutational analysis of the RPGRIP1L gene in patients with Joubert syndrome and nephronophthisis. Kidney Int 72:1520-1526

18. Ozcelik T, Akarsu N, Uz E, Caglayan S, Gulsuner S, Onat OE, Tan M, Tan U (2008) Mutations in the very low-density lipoprotein receptor VLDLR cause cerebellar hypoplasia and quadrupedal locomotion in humans. Proc Natl Acad Sci U S A $105: 4232-4236$ 
19. Türkmen S, Hoffmann K, Demirhan O, Aruoba D, Humphrey N, Mundlos S (2008) Cerebellar hypoplasia, with quadrupedal locomotion, caused by mutations in the very low-density lipoprotein receptor gene. Eur J Hum Genet 16:1070-1074

20. Moheb LA, Tzschach A, Garshasbi M, Kahrizi K, Darvish H, Heshmati Y, Kordi A, Najmabadi H, Ropers HH, Kuss AW (2008) Identification of a nonsense mutation in the very low-density lipoprotein receptor gene (VLDLR) in an Iranian family with dysequilibrium syndrome. Eur J Hum Genet 16:270-273

21. Boycott KM, Flavelle S, Bureau A, Glass HC, Fujiwara TM, Wirrell E, Davey K, Chudley AE, Scott JN, McLeod DR, Parboosingh JS (2005) Homozygous deletion of the very low density lipoprotein receptor gene causes autosomal recessive cerebellar hypoplasia with cerebral gyral simplification. Am J Hum Genet 77:477-483

22. Pallister PD, Opitz JM (1985) Disequilibrium syndrome in Montana Hutterites. Am J Med Genet 22:567-569

23. Schurig V, Orman AV, Bowen P (1981) Nonprogressive cerebellar disorder with mental retardation and autosomal recessive inheritance in Hutterites. Am J Med Genet 9:43-53

24. Hagberg B, Sanner G, Steen M (1972) The dysequilibrium syndrome in cerebral palsy. Clinical aspects and treatment. Acta Paediatr Scand Suppl 226:1-63

25. Bayrakli F, Bilguvar K, Mason CE, DiLuna ML, Bayri Y, Gungor L, Terzi M, Mane SM, Lifton RP, State MW, Gunel M (2007) Rapid identification of disease-causing mutations using copy number analysis within linkage intervals. Hum Mutat 28:1236-1240

26. Wang K, Li M, Hadley D, Liu R, Glessner J, Grant SF, Hakonarson H, Bucan M (2007) PennCNV: an integrated hidden Markov model designed for high-resolution copy number variation detection in whole-genome SNP genotyping data. Genome Res 17:1665-1674

27. Rozen S, Skaletsky H (2000) Primer3 on the WWW for general users and for biologist programmers. Methods Mol Biol 132:365-386

28. Altschul SF, Gish W, Miller W, Myers EW, Lipman DJ (1990) Basic local alignment search tool. J Mol Biol 215:403-410

29. Sakai J, Hoshino A, Takahashi S, Miura Y, Ishii H, Suzuki H, Kawarabayasi Y, Yamamoto T (1994) Structure, chromosome location, and expression of the human very low density lipoprotein receptor gene. J Biol Chem 269:2173-2182

30. Tacken PJ, Hofker MH, Havekes LM, van Dijk KW (2001) Living up to a name: the role of the VLDL receptor in lipid metabolism. Curr Opin Lipidol 12:275-279
31. Hiesberger T, Trommsdorff M, Howell BW, Goffinet A, Mumby MC, Cooper JA, Herz J (1999) Direct binding of Reelin to VLDL receptor and ApoE receptor 2 induces tyrosine phosphorylation of disabled-1 and modulates tau phosphorylation. Neuron 24:481-489

32. Miyata T, Nakajima K, Mikoshiba K, Ogawa M (1997) Regulation of Purkinje cell alignment by reelin as revealed with CR-50 antibody. J Neurosci 17:3599-3609

33. D'Arcangelo G, Miao GG, Chen SC, Soares HD, Morgan JI, Curran T (1995) A protein related to extracellular matrix proteins deleted in the mouse mutant reeler. Nature 374:719-723

34. Trommsdorff $M$ et al (1999) Reeler/disabled-like disruption of neuronal migration in knockout mice lacking the VLDL receptor and ApoE receptor 2. Cell 97:689-701

35. Frykman PK, Brown MS, Yamamoto T, Goldstein JL, Herz J (1995) Normal plasma lipoproteins and fertility in gene-targeted mice homozygous for a disruption in the gene encoding very low density lipoprotein receptor. Proc Natl Acad Sci U S A 92:8453-8457

36. Boycott KM, Bonnemann C, Herz J, Neuert S, Beaulieu C, Scott JN, Venkatasubramanian A, Parboosingh JS (2009) Mutations in VLDLR as a cause for autosomal recessive cerebellar ataxia with mental retardation (dysequilibrium syndrome). J Child Neurol $24: 1310-1315$

37. Tan U (2006) A new syndrome with quadrupedal gait, primitive speech, and severe mental retardation as a live model for human evolution. Int J Neurosci 116:361-369

38. Türkmen S, Demirhan O, Hoffmann K, Diers A, Zimmer C, Sperling K, Mundlos S (2006) Cerebellar hypoplasia and quadrupedal locomotion in humans as a recessive trait mapping to chromosome 17p. J Med Genet 43(5):461-464. Epub 2005 Dec 21

39. Türkmen S, Guo G, Garshasbi M, Hoffmann K, Alshalah AJ, Mischung C, Kuss A, Humphrey N, Mundlos S, Robinson PN (2009) CA8 mutations cause a novel syndrome characterized by ataxia and mild mental retardation with predisposition to quadrupedal gait. PLoS Genet 5:e1000487

40. Ozcelik T, Akarsu N, Uz E, Caglayan S, Gulsuner S, Onat OE, Tan M, Tan U (2008) Reply to Herz et al. and Humphrey et al.: genetic heterogeneity of cerebellar hypoplasia with quadrupedal locomotion. Proc Natl Acad Sci U S A 105:E32-E33

41. Herz J, Boycott KM, Parboosingh JS (2008) "Devolution" of bipedality. Proc Natl Acad Sci U S A 105:E25

42. Humphrey N, Mundlos S, Turkmen S (2008) Genes and quadrupedal locomotion in humans. Proc Natl Acad Sci U S A 105:E26 